VADYM BESPEKA,

National Army academy named after hetman Petro Sahaydachniy (Lviv, Ukraine)

e-mail:vadim12323@ukr.net, ORCID0000-0001-6934-1610

\title{
USA PROPAGANDA IN COLD WAR PERIOD: FORMATION OF THE IMAGE OF ENEMY IN FACE OF THE USSR
}

\begin{abstract}
The analysis of asymmetric threats in past armed confrontations makes it possible to evaluate the risks in similar situations today. The Cold War of 1946-1991 is not an exception, because the experience of using propaganda influence by both parties in it is an inexhaustible source for generalization and predictions of the processes around the Russian-Ukrainian conflict, which are gradually described by modern military and political experts as the "Cold War of the XXI century". Publications existing in the post-Soviet space largely suffer from the orthodoxy of their views. This limits the ability to evaluate objectively the forms and methods of forming public opinion in the United States regarding a political enemy after the Second World War, and thus impoverishes knowledge of possible options for the unfolding of events for our country in the opposition of such type, and, accordingly, the ability to predict the situation. The proposed study attempts to differentiate itself from Soviet and post-Soviet sources of information and, based solely on US publications, to identify the main cliches formed in the US information space regarding the image of the enemy in the face of the USSR.
\end{abstract}

Keywords: the Cold War; image of the enemy; propaganda; read menace; nuclear threat; the Iron Curtain.

\section{Introduction}

During the analysis of events in the international arena at the beginning of the 21st century, the manifestations of confrontation between the USA and the Russian Federation are traced. Political scientists and military experts have already described it as the "new Cold War." The question is the following: what should the world expect in this situation? Certain answers to this question can be found by projecting appropriate processes from the experience of the Cold War of 1946-1991 to the events of today. The relevance of the study of the problem is due primarily to the fact that fundamental works on the study of the American view of the Cold War are almost absent in Ukraine. Instead, native historiography (as in other post-Soviet countries) is oversaturated with editions of the Soviet period that not only cover the researched events non-objectively, but also often mislead regarding the real state of affairs.

There is a considerable amount of researches in the United States of America that reveals the events of the Cold War in various aspects of its manifestation. American researchers have often touched upon the question of propaganda of the sides in this confrontation and, in particular, the formation of the image of the USSR as an ideological opponent. However, the information about it is scattered. Thus, most authors have examined this "cold confrontation" in the context of the American government's propaganda activities (Parry-Giles, 1994), (Barsamian, 1992), (Sproule, $1987)$ or the US foreign policy activity (Entman, 1989), (Gamson, 1992), (Garthoff, 1985). The work of American author L. W. Holstein "Framing the enemy: changing u.s. media images of CHINA and the U.S.S.R. at the end of the Cold War", in which she examines the impact of US news on the "framing" of the enemy in the minds of US citizens by comparing the coverage of events in two communist countries at the end of the Cold War, deserves special attention (Holstein, 2002). An attempt to research the image of the enemy of the USSR in American print editions has been made by another American researcher W. H. Chang (Chang, 1991). Thus, the historiographical basis on the proposed subject provides a broad material for the study and author's generalization of materials in order to fill the fragmentarity of presentation in the postSoviet space of the problem of the American view of the processes of forming of the image of enemy in the USSR and the US in the second half of the twentieth century.

The purpose of the research: scientific analysis of the process of formation of the image of enemy in face of the USSR in American society during the Cold War period and expression of its main points in the information space of that time.

To achieve this purpose the following research tasks are set: 1) to identify the main points of US government propaganda about the USSR aimed at the formation of permanent psychological patterns of citizens of the country; 2 ) to discover "channels of transmission" of propaganda information to the audience; 3 ) to trace feedback (reaction) from the American audience to the information and psychological impact.

\section{Methods}

During the development of the information base, a wide range of research methods was used. In particular, the historical-comparative method, which provides for the use of analogy, made it possible to compare interpretation of historical events and political processes by different sources on the basis of concrete facts. This method was greatly helpful for the study of the similarity of individual cases of effect on the audience with the known general features of propaganda forms and methods. The systematic approach made it possible to examine both propaganda and people's response to it, both the development of an ideologeme and its practical application to US 
society during the Cold War. In turn, the system-structural method, based on structural analysis, led to the implementation of a multi-level approach to the elements of the system of information influence as such.

\section{Results and Discussion}

The formation of the image of the enemy in mind of an American citizen began long before the start of the Cold War. Thus, even with the beginning of revolutionary events in the Russian Empire, the American elite was aware of the danger to the political order of the country, since, as it is known, the Bolsheviks declared capitalism their main enemy, adopting the slogan of Marxism: "... the first step in the world revolution is to raise the proletariat to the position of ruling class to win the battle of democracy" (Marx, Engels, 1848: 446). Consequently, the leadership of the United States of America found it necessary to respond to the expansion of the ideological influence of the communist party, which began to increase its activity, including in the territory of the United States. The statement of then Secretary of State R. Lansing is illustrative in this regard: "... The Bolsheviks are a direct threat to the existing system in all countries ... They must be destroyed because they offered the doctrine of radical class struggle to the ordinary man, instead of national patriotism, which is their fundamental mistake"1. In fact, American historians identify the period from the 1920s to the late 1930s with the notions "red panic" and "witch hunt".

Taking into account developments in the international arena and considering own geopolitical interests, in 1930, the United States Congress overwhelmingly adopted a law "On the establishment of the Committee on Communist Oversight in the United States". And in 1931, the first head of this committee, H. Fish published a report "The Menance of Communism", in which he gave the generalized characteristic of the phenomenon. In particular, he noted: "Communism is the most important, the most vital, and the most far-reaching issue in the world, affecting the civilization of the world and the happiness and safety of our people. The merits and the demerits of prohibition sink into insignificance compared to this question of Communism, whose ramifications reach into every human sphere and activity, and which is a great world issue" (Fish, 1931: 54). The politician considered the propaganda activity carried out by the media under the control of the communist party as an individual threat. In particular, he emphasized: "There are 11 or 12 daily Communist newspapers, with a total circulation of 264,000 . All except one are in foreign languages. They are spreading the most vicious, poisonous hatred against everything in which we believe in this country, against our institutions and our government and our flag, among aliens and naturalized foreigners who ought to be good citizens. Those 264,000 papers are not read simply by one person each, but by entire families" (Ibid: 56).

The committee headed by $\mathrm{H}$. Fish called for specific measures against the "Communists" and declared the Communist Party illegal in the United States (Buhle, Jo, Buhle, and Georgakas, 1997: 334). Later, in 1934, this institution was transformed into the House Un-American Activities Committee, HUAC. Its main purpose was "... to combat subversive and anti-American propaganda" (Morris, 1982: 424). One of the significant results of the Committee's work was that the mass media supported

\footnotetext{
Department of State, Papers Relating to the Foreign Relations of the United States, Russia, 1918, vol. 1, Robert Lansing to David Francis, March 20, 1917, (Washington D.C: U.S. Government Printing Office, 1931), 12.
}

the position of the government and American elites, which gave a corresponding boost to the introduction in the early 1920 s of the phrase "red threat" into the American lexicon.

So, it can be assumed that the process of formation of the image of enemy in face of the USSR in the minds of American society was put on a "pause" during the Second World War. At the same time, we believe that the US perception of the Soviet Union as an ideological opponent was formed long before the Cold War, was laid up because of military and political problems during the Second World War, and re-emerged in the post-war period. The short "friendly-allied" period ended almost simultaneously with the battle actions.

Almost immediately, American books, films and brochures began to warn that the USSR was seeking dominance in the world. It was especially evident in the late 1940 s and 1950s. Thus, with the help of print media, the public idea of active preparation of the USSR for war with the United States is fostered. There are several examples: series of articles from "Life" journal: "Report on the Power of Russia: The Soviet Union Builds a Great Machine for War" (August 9, 1948) and "How Close Are We to War with Russia?" (September, 1948); the "Look" and "Evening Post" newspapers came out with headlines "How Ready Are We If Russia Attacks?" (June 20, 1950); "Post" printed publication: "I Saw Russia Preparing for the Third World War" (July 2, 1949), "Now They Know What the Red Conquest Means" (November 25, 1950), and "Stalin's Secret Military Plans" (September 20, 1952). In the aforementioned publications, the American reader was asked to consider the following questions: "Can we survive? In our nation's history this issue has never been more urgent ... A successful attack on us can give the ruthless Communist leaders control of the world in a week" (Drake, 1958: 43).

The main image-forming associations of the USSR as the enemy of the US in our opinion were: "red threat", "Soviet bear", "Iron Curtain", "Nuclear Fear". The characteristics of each of them in more detail is presented below.

As we can see, the "red panic" permeated many spheres of American life in the first post-war decade, because absolutely all public officials and industrial workers were virtually "forced" to swear publicly in their allegiance to the United States. Being a "real" American then meant that you could not be a communist. Moreover, even before the end of the Second World War, Americans who joined the Communist Party were considered a threat to the nation (Barson and Heller, 2001: 97). Thus, under the direction of J. Hoover, the Federal Bureau of Investigation ( $\mathrm{FBI}$ ) took the initiative to warn the society that Communists live among citizens. It is interesting that in 1947 the bureau gave to the "NewsWeek" newspaper a piece of material - instruction called "Ten Don'ts by Mr. Hoover". In particular, in this message, J. Hoover stated, "... We can successfully defeat the Communist attempt to capture the United States by fighting it with truth and justice, implemented with a few don'ts: 1) Don't label anyone as a Communist unless you have the facts. 2) Don't confuse liberals and progressives with Communists. 3) Don't take the law into your own hands. 4) If Communists violate the law, report such facts to your law-enforcement agency. 5) Don't be a party to the violation of the civil rights of anyone. When this is done, you are playing directly into the hands of the Communists. 6) Don't let up on the fight against real Fascists, the KKK, and other dangerous groups. 7) Don't let Communists in your organization or labor union outwork, outvote, or outnumber you. 8) Don't be hoodwinked by Communist propaganda that says one thing but means destruction of the American way of life. 9) Expose it with the truth. 10) Don't let Communists infiltrate into our schools, 
churches, and molders of public opinion - the press, radio, and screen" (Hoover, 1947: 31).

It should be noted that Hoover's warnings to be careful with the new enemy were fairly restrained, not aggressive. Their purpose was not to scare the Americans, but to encourage them to take actions: "Be vigilant, but don't overdo it". The FBI Director's appeal was addressed to every American, thereby engaging the entire society in the fight against the growing "red threat".

The ideological confrontation involved all sectors of civil life in the United States. The film industry did not remain aside the opposition to communism. Among the striking examples, above all, the feature film "The Iron Curtain", directed by W. Wellman, should be noted. According to American scientists, it was precisely that film that "triggered" a series of films about the "red danger" of the period. The plot tells about the Soviet clerk lieutenant I. Gouzenko, who served at the Soviet Embassy in Ottawa. While working there, the officer provided the Government of Canada with 109 pieces of evidence that his colleagues had stolen secret files about nuclear bomb making. But he provided information that revealed about 20 Soviet spies, including those who worked in the President F. Roosevelt's administration. In the film, it's main emphasis can be seen, namely, at the end the family of an officer walking along a sunny country road, followed by two government guards, is shown ${ }^{2}$. The filmmakers emphasize that the informant and his family received reliable government protection against possible harassment by the Soviet secret police. At the same time, an important warning was sent to the broad masses - "red spies" would be found even in the highest government authorities.

In 1995, British Prime Minister M. Thatcher emphasized the importance of the officer's deed in a letter to the wife of I. Guzenko: "When you and your husband defected to freedom, you began a long process that eventually led to the collapse of the Soviet Union. His evidences helped the West meet the realities of communist subversive activity and tyranny..."3.

Another, equally important category of citizens came under anti-communist influence was children and adolescents. The forms of distribution of the information were mostly graphic and easy for perception, as well as accessible to any segment of the American population. For example, in 1951, the opportunity to play with a new brand of chewing gum cards in a series called "Children's Crusade Against Communism" was offered to American children. Under the chewing gum cover, children found stories about a "red threat". In our opinion, a vivid example was: "Card № 23 - Ghost City". The picture is an artist's idea of what an atom bomb could do to a great American city. The Reds like us to think of this. They think it will make us afraid. But actually, we are growing stronger by realizing that this could happen to us. We are working to make America stronger day by day, week by week. We must continue to work for peace through the United Nations and in every possible way. But an America fully prepared to defend itself is not likely to be attacked. The Reds understand this language. Fight the red menace!"4. The striking characteristics of the threat from the USSR influenced on

\footnotetext{
2 The Iron Curtain (1948). Retrieved from: https://www.youtube.com/watch?v=Ea-mphnYh-4 (Accessed 25 March 2019).

3 The Monitor (1987). Retrieved from: https://www.cbc.ca/archives/ entry/mrs-gouzenko-shows-her-face (Accessed 19 May 2019).

${ }^{4}$ Bowman Gum Company (1951). Fight the Red Menace: The Children's Crusade against Communism trading cards. Retrieved from: https://www.gilderlehrman.org/collection/glc09706 (Accessed 21 May 2019).
}

the formation of a certain position against communism of collectors of this type of cards. Calling the children to fight, the government emphasized the degree and extent of cunning and aggression of the Soviet Union, which required the readiness of all to be part of the team in the fight against the "red menace".

It should be emphasized that the constant presence of the "Soviet threat", in all spheres of life of ordinary Americans, helped the US government, on the one hand, in laying the fear to the enemy, but on the other - In the consolidation in surveillance over the Communists and determination in confronting them. The result of the work of American propaganda bodies was that the average Americans were seriously determined to confront the USSR and also fully trusted government information. According to the Americans, the "Reds" were aggressive and had their own predatory plans for the whole world. And the term "red" was associated with the Soviet Union and symbolically accompanied by hostility, deception and violence.

The constructed identity of the Soviet Union held these concepts so deep that the subtext of the words "red" or "Soviet red" contained a negative connotation in American discourse throughout the cold war between superpowers.

Another metaphorical image of the country of the Soviets, which formed a hostile attitude towards the Soviet Union among Americans and rooted in their minds in the postwar period, became the so-called "Iron Curtain". It should be noted that the idea that the world was divided into two parts gained popularity shortly after the end of the Second World War.

As confirmation, the events of March 5, 1946 are worth recalling. Then, for the first time in a while, after W. Churchill's speech in Fulton, American society looked at international communism, the epicenter of which was the USSR, from a different angle. The following words from a British politician's speech are the most striking fromn this perspective: "...A shadow has fallen upon the scenes so lately lighted by the Allied victory. Nobody knows what Soviet Russia and its Communist international organization intends to do in the immediate future, or what are the limits, if any, to their expansive and proselytizing tendencies. ... From Stettin in the Baltic to Trieste in the Adriatic, an iron curtain has descended across the Continent. Behind that line lie all the capitals of the ancient states of Central and Eastern Europe. Warsaw, Berlin, Prague, Vienna, Budapest, Belgrade, Bucharest and Sofia, all these famous cities and the populations around them lie in what I must call the Soviet sphere, and all are subject in one form or another, not only to Soviet influence but to a very high and, in many cases, increasing measure of control from Mos$\mathrm{cow}^{\text {"5}}$. Many researchers of W. Churchill call namely this W. Churchill's speech a declaration of the Cold War to the Soviet Union. But for us, it is also interesting because of the fact that such a propaganda phrase as the "iron curtain" captured the thoughts of the American people. In doing so, it woke the pre-war fear of a communist threat.

After the British Prime Minister's designation of the "Iron Curtain" as a symbol of the post-war division of the world into two ideologically different camps, the use of this term became common. During the postwar period, it symbolized the "buffer" that surrounded the "Soviet empire" and served as a metaphor for describing Soviet identity.

Therefore, in order to show most clearly all the negativity of the communist system, the US leadership had chosen

5 Churchill's Iron Curtain Speech (1946), Retrieved from: https:// www.youtube.com/watch?v=X2FM3 h33Tg (Accessed 21 May 2019). 
a method of comparing and opposing it to the familiar American values and the American way of life.

As time passed, in a speech in 1954, CIA Director A. Dulles formulated the purpose of the "Iron Curtain", which in his view was the following: "The Kremlin, through its own actions, made it clear that the desire for freedom of the peoples under Soviet control was the main threat to the leaders of the Soviet Union". He gave following arguments of it: "... The Soviets never could stand free elections and will never allow doing so... They have set the "Iron Curtain" to prevent free people from entering their country and to prevent their own people from leaving the borders of the USSR. The "Iron Curtain" is a cold reality of steel, barbed wire and watchtowers" (Dulles, 1954: 869).

A. Dulles's description of "Iron Curtain" suggested that the borders of Eastern European countries were surrounded by an iron fence. In his view, the "Iron Curtain" was a completely metaphorical image that was often used by politicians and American society to describe a part of the world controlled by USSR, except for the Berlin Wall that isolated West Berlin from East Germany. The image constructed by the metaphor was similar to a cage: its steel bars held those who lived behind it. The freedom to move, think and choose was restricted with these steel rods.

Considering in more detail the characteristics of the "Iron Curtain" and their contribution to the forming of the image of the Soviet Union as an enemy among the Americans is proposed.

It is easy to link this metaphor to the then-American perceptions of the population of the USSR and its satellites, which could not move freely across this barrier, since travel for people behind it was severely limited. Throughout the postwar period, the concept of the United States as a free people country with their "hospitable shores" was opposed to the concept of the Soviet Union as a country of oppressed people suffering through their isolation from the entire democratic world. The second feature of the metaphorical structure was that the "curtain" prevented strangers from looking inside, so there was a feeling of secrecy about what was actually happening, so to speak, behind this iron fence.

In the view of most Americans, the "Iron Curtain" surrounded most of Eastern Europe from its neighbors in the West as a barrier. And for its persistence, the Soviet Union controlled these countries tightly.

During his public speeches, the American politicum constantly emphasized the Communist leaders' disrespect for the people on the other side of democracy. The Soviet and Eastern European peoples were represented in speeches as people without right and voice, and therefore they could not demand another political, economic or social system. The participation of Soviet citizens in the elections, despite the high level of voter turnout, was limited to voting between pre-nominated Communist candidates.

Senator R. Taft drew attention to this in 1952, in one of interviews, talking about people under Soviet influence: "... the peoples of Eastern Europe are captive slaves who are forced by the Soviet satellite governments against their will to serve the cause of the tyranny of the Soviet Union. We should use local underground agencies in every oppressed country, whose members, like us, believe in freedom, but much better than us know with the help of what means people can be turned to our side. There are millions of heroic anti-Communist Russians, Poles, Lithuanians, Ukrainians, Slovaks, Czechs, Romanians, Hungarians, Bulgarians, Latvians who want to overthrow the Soviet yoke and regain independence and freedom" (Taft, 1952: 517).

ISSN 1728-9343 (Print)

ISSN 2411-3093 (Online)
The fact that the identity of the United States is based on the idea of freedom was a key difference in comparing the lives of people in opposing systems. Describing the representatives of Eastern Europe as bound, R. Taft aimed at revealing their utter helplessness to their leaders in the country of residence. That is why Soviet power was presented to Americans as illegitimate - and above all because people were not able to choose their own politicians freely. The American model, on the contrary, gave people complete freedom of expression of will.

The post-war administrations of US presidents shaped public opinion in such a way that totalitarian states were inherently aggressive and "democratic states only use force when they are forced to respond to totalitarian aggression" (Weldes, 1999: 128).

Analyzing the sources of information given to American citizens, religious institutions should not be overlooked, since freedom of religion was extremely important to many US residents. It should be noted that both the Protestant and Catholic American churches, along with the political circles of the state, were worried about a new threat from the USSR. They emphasized the danger of communism, in particular in that in the USSR they imposed atheistic views on their citizens. As conformation of this, there was an interesting document entitled "Instructions to Catholic Priests on How to Behave Towards Repentant Communists". It states, among other things: "... the holy church still opposes communist ideas and parties. But since then, every churchman who is convinced that the ex-communist was not sufficiently free to take his wrong steps can declare forgiveness of sins without unnecessary formalities" (Weisberg, 1999).

We should mention again that anti-communist propaganda in the United States covered a wide range of sectors of people. A striking example is the impact on female audiences. Thus, American journalist J. Whitney in 1954 published a series of articles called "Women Russia's Second-Class Citizens", in which she accused the USSR of contemptuous disregard of women. In particular, she wrote "...a woman in Russia has a chance to be almost anything, except a woman. Even today, in a relatively cosmopolitan Moscow, a good-looking, welldressed girl wearing make-up is one of three things: a foreigner, an actress or a prostitute .... The majority of statues of women in Russian parks wear brassieres and gym pants! Needless to say, there is no 'Miss U.S.S.R."'", the journalist concludes. The American reporter emphasizes that in Moscow, with its population of five million, "there are just two beauty parlors which by Western standards deserve the name. The other half-dozen are 'medical cosmetic institutions" (Whitney, 1954).

Another element of the opposition of the two systems that shaped the American public perception of the USSR as a country behind the "Iron Curtain" was the difference in coverage of the foreign policy activities of the two superpowers - the Soviet Union and America.

While post-war economic and military US interventions in developing countries were covered in US media solely as a noble intention to modernize and improve living standards, Soviet motives were colored as clearly negative. The interpretations were as follows: the expansion of the "Iron Curtain" guaranteed the parallel expansion of totalitarianism. And the United States, by contrast, was represented by the creators of the "pluralistic world" as the main aspect of their democracy to others (Stevenson, Richard, 1962: 729).

A vivid example is the anti-Soviet performances in Eastern Europe. When the Soviet military force was used to suppress the uprising in Hungary in October 1956, the 
US media emphasized the aggressiveness of the Soviet system towards a country that dared to look through the "Curtain". President D. Eisenhower commented these events as follows: "... In Eastern Europe we see a spirit of freedom - fast and strong - piercing darkness. The people of Poland and Hungary, as brave as ever throughout their history, sacrificed their lives to gain freedom ... In all this, the true intentions of the Soviet Union seem to us even more incomprehensible. We are concerned about the news of the Soviet Union's new efforts to suppress forcibly the freedom of expression of the people of Hungary. We have always made it clear that we will never give up our care of these lands and people. Before the UN World Forum, we have condemned the use of force by the USSR in its attempt to suppress the uprising of these peoples. And we have refrained from using force, knowing that it is contrary to the interests of these peoples as well as to the spirit and methods of the United Nations .. "6. Privacy and complete secrecy were the next features of the "Iron Curtain". Along with stories about the events inside of the Soviet Union, which were reported in the US press, there were stories about how the Soviet government tried to restrain or control the transmission of information inside the country. The "Time" message about the death of J. Stalin, March 23, 1953 is a vivid example: "This week's cover is dedicated to Russian Prime Minister G. Malenkov and J. Stalin. The facts of Stalin's death and G. Malenkov's political succession were the most significant news that broke through the "Iron Curtain" since the Second World War. But the fullness of these facts can only be ensured through the analytical filling of some of the gaps ... And you often wonder how many facts you can collect (with the help of a bunch of tips, hard work and experience) about the events that the most powerful police state in the world is trying to hide. It all illustrated some of the difficulties connected to covering news from Russia these days"7.

Secrecy and insincerity were also connected with the Soviet Union's attempts to drag other states into the middle of the "Iron Curtain" through deception and propaganda. According to the director of the American Institute of Public Opinion, G. Gallup, the USSR had to rely on "propaganda" as the only way to interest other nations in its ideology. $\mathrm{He}$ stated the following: "Any person feels an irresistible desire to improve the economic sphere of his or her life. The Communists realized this. As a result, the simple promise of a good life thanks to communism called for millions to come to their side. Russia has carefully cultivated the idea that the Communists are friends and protectors of the helpless, a hope for the oppressed. It is important to point out that the promise can be completely untrue and insincere. However, people do not tend to doubt too much the morals of those who sympathize with them. People who live a miserable life are ready to follow anyone who gives the least hope for a better life. And with all the progress in the world, the question most often posed by the people who inhabit this earth is very simple: "when will we eat?" (Gallup, 1952: 502-503).

In the dystopian novel by G. Orwell, entitled "1984", the control over information by the so-called Ministry of Truth, under the slogan of social harmony, as well as the total control over citizens by security services, is clearly revealed. In particular, the following lines are found in the work: "...And if all others accepted the lie which the Party imposed - If all records told the same tale - then the lie passed into history and became truth. 'Who controls the past' ran the Party

\footnotetext{
${ }^{6}$ The Washington Post and Times Herald (2 November 1956), Text of President's Philadelphia Speech, p.10.

7 Time, (March 23, 1953), Watch on the Wall. p. 27-28.
}

slogan, 'controls the future: who controls the present controls the past" (Orwell, 1949: 231). In 1949, about 400,000 copies of this book were sold and it was included in the education programs of US schools and colleges ${ }^{8}$.

Therefore, for the average American citizen, there was not only a curtain in the political sphere, but also in all matters of life, between the USSR, its satellites and the rest of the world. Concluding, it should be noted that the "Iron Curtain", first of all, awakened in the minds of American citizens the feeling that something absolutely unacceptable was hidden behind it, something that was incompatible with such a precious for a US citizen "American way of life".

Describing the main points of American propaganda that surrounded the formation of the image of the USSR as an enemy, it is impossible to overlook the image of it as a big bear. It was successfully used in the postwar period. In American propaganda, it was a slow but large, dangerous, repressive, secretive and threatening beast.

It should be emphasized that the concept of identifying the bear with all the elements specific to the USSR and the totalitarian communist system was reflected in all spheres, including the Soviet leadership, power structures, the economy and the Soviet people themselves. Here is an example. Thus, in January 1946, a central map, illustrating the growing area of territories that came under Soviet control in Europe and parts of Asia, was published on the pages of the "New York Daily News" Sunday journals. The title of the article reflected the content - "The Bear Grows and Grows". The editorial staff of the journal emphasized: "Stalin is set to strengthen its sprawling "ear" on all sides with territorial "pillows". In addition, Russia continues to expand its "zone of influence": from strong political pressure to absolute political supremacy ... The "Soviet Bear" began to establish a new presence in the regions, including regions beyond the territories it had acquired at the end of the Second World War under the Yalta Agreement in $1945^{\prime \prime}$.

Not only the Soviet state, but also its leaders were associated with the image of the bear. And most of these comparisons are found in the descriptions of $\mathrm{N}$ Khrushchev. Thus, in an article titled "Little Bear", on April 29, 1957, the "Time" newspaper reported: "... the first Party Secretary, Nikita Khrushchev reached the age of 63 last week, and he, like a red Russian bear, burst into the Moscow reception area with embraces and teasings, hamstrings, slaps and clappings in front of his surprised guests .... The mood of the bear was constantly changing from cheerful to extremely aggressive. At the Prime Minister of Poland J. Cyrankiewicz' reception, the expansive Nikita was joking again and again about how many times "our troops were in Poland and your troops were in Moscow". He joked about the Polish prime minister in a sweat over the ongoing economic assistance talks between the USA and Poland: "Comrade Cyrankiewicz, you are groomed and looked after like a bride, but it is not because you are beautiful and young". After that, the bear lifted its heavy paw upward, pointing a warning gesture with his finger ${ }^{10}$

In fact, in our opinion, Khrushchev was described in terms that characterized rudeness, cruelty or seeming naivety most of all. "Time", dated July 15, 1955, called him a "sharp" and "careless character with greater vigor and

\footnotetext{
${ }^{8}$ Charles' George Orwell Links, Retrieved from: https://web.archive.org/web/20110718093026/http://www.netcharles.com/ orwell/books/1984.htm.

${ }^{9}$ New York Daily News (January 1946), The Bear Grows and Grows.

10 Time (April 29,1957), The Tiddly Bear, pp. 28-29.
} 
passion than others, and a peasant's inherent cunning", suggesting that reasons for political success were his stubborn determination and cunning rather than his political sophistication ${ }^{11}$.

We can see about the same image of this politician in the American press 9 years later. Thus, in 1964, the "Time" issue of November 13 reported on his "boorish" behavior. In particular, the publication printed lines with the following content: "As a female bear protecting the area around its offspring, the Soviet leader was considered a defender of the territories and people under his control (especially when challenged by the United States) but remained too clumsy in his attempts something to counteract"12

In general, when the point was the Soviet leaders, Americans emphasized their inappropriateness and lack of expression for the role of leader or official representative of the superpower. For Americans, success in diplomatic work depends in part on personal qualities, for example, on the ability to engage in difficult and serious negotiations, to pause, to be flexible. In contrast to these principles, the Soviet leaders behaved like bears: they were capricious and predictable. The portrait of a Soviet leader or politician, in the postwar period, was usually emphasized in the media, recalling the deficiencies or peculiarities of their appearance, manner or personality. Even when it came to something positive, the text was astonishing, reminding the reader that it was an exception to the rules.

For example, describing the behavior of the Chairman of the Council of Ministers of the USSR, N. Bulganin, during a formal meeting, "Time", dated July 15, 1955, emphasized his failed attempts to harmonize with other politicians. The text of the article states: "Even a custom-tailored striped suit and the use of slow phrases and old-fashioned manners did not add to authority to the Soviet leader. Despite the fact that he considered "polished" nails and the fact that "he never spills his soup", Bulganin clearly did not fit into the club of world leaders. If he did not have such position, Bulganin could have allowed his beard to grow and could have become a Soviet "schweppesman" depicted on bottles"13

American propaganda also endowed intelligence agencies with the characteristics of the "bear's clumsiness". Thus, according to the leading media in the United States, during the Cold War, the KGB, Soviet intelligence and the country's internal security organs were like a mirror image of their leaders.

Thus, in the October 11, 1971 issue, one of the "Time" correspondents described his experience of meeting with a KGB agent who tried to retrieve from him information about the leaders of the "Prague Spring" under the pretext of conducting a sociological study of the event. The article states: "The scout, named "Roger Smith", identified himself as an American scientist. With a rough Slavic accent, he balanced for a few minutes between the street jargon and the partially ridiculous outdated American slang that could be heard last in 1930s films. To my questions, he confessed to being affiliated with "Seattle University - you know, in Oregon". When I asked him about the current price of "McDonald's" hamburgers, he shrugged it off: "I came straight from the States. I haven't been to Scotland lately". After a dozen attempts to find out at least some information, my interlocutor joked: "You are not a very experienced employee, are you?". I assured him that I would do much better with my job than he did with his own"14. As we can

\footnotetext{
11 Time (July 18, 1955), The Chummy Commissar, pp. 16-20.

12 Time (November 13, 1964), The Era of Many Romes, pp. 44-45. 13 Time (June 10, 1955), Prelude to the Parley, pp. 15-18.

14 Time (October 11, 1971), Spies: Foot Soldiers in an Endless War, pp. $41-48$
}

see, the Soviet spy is portrayed as arrogant, naive and incompetent, while the American is intelligent and patient. Only at the end of the conversation the Soviet agent realized that he had been deceived, which showed again that the insane "Russian bear" could not match the keen scent of "American eagle".

It should also be emphasized that information about the Soviet people, in general, was no exception, when being compared with the "Soviet bear". The population of the USSR is often presented as something gray, patient and suffering. Being in a system that did not count with their individual desires or tastes, a Soviet citizen was usually portrayed as part of a socialist machine, a component prepared to accomplish the tasks for the good of the country.

Thus, according to the publications of the American media, the Soviet women's concepts of style were just as gloomy and unattractive. Describing Soviet women, they portrayed them colorless and amorphous in form. The "model of Soviet womanhood" was to be happy in fulfilling its responsibilities and "contributing to the five-year plan" (Willis, 1985).

These descriptions proved that American style was better than Soviet fashion, just as American leaders were better than Soviet leaders and American spies were smarter than Soviet spies. The Soviet system, in which people lived, was planning absolutely all aspects of production and distribution, but remained slow and indifferent to the interests of ordinary people.

Control by the Soviet central government was a major topic of American propaganda. Since the CPSU Central Committee planned all aspects of the economy, there was no effectiveness from such actions. Because the Soviet economy was oriented towards meeting military needs, consumer needs were not taken into account. Despite technological advances in military power, there were no real innovations to support the needs of the common man in the USSR.

The articles and stories about the inefficiency of the Soviet economy were intended to convey to the American reader the extent of the unmet needs of the Soviet consumer. A striking example is found in the "Time" issued on July 13, 1962: "About four years ago, there were so many toothbrushes that the State Planning Committee decided that there were too many of them. In 1959, Moscow reduced its annual output from 15 million to 6 million, converting production to produce artificial flowers and plastic toys. The production of toothbrushes in Ukraine had practically stopped. The mistake was discovered only in early last year when toothbrush stocks were dangerously low. They quickly set the aim to produce 48 million toothbrushes in 1962. The wastefulness of the entire system was emphasized by every unproductive step in the process, including the time spent deciding on production cuts ${ }^{15}$.

In addition, in many descriptions of a Soviet citizen, the harshness made Americans think of the enormous burden that people in the USSR carried. "Dense, milky clouds hung high above Moscow, and a sharp northerly wind tore the last leaves off the birch". However, even in the harsh Russian winter, there was a moment of hope. The new Russian regime has announced that, for the first time in 13 months, according to the standardization of grain, each citizen will be given 4.5 extra pounds of flour for cabbage pies, which are vital for the Russian soul"16. Thus, "Time", on November 6,1964, described the strict methods of

\footnotetext{
${ }_{15}$ Time (July 13, 1962), The Bristle Gap, p. 36.

${ }^{16}$ Time (November 6, 1964), How Nikita and Nina Came Back to No. 3 Granovsky Street, pp. 26.
} 
Soviet economic planning that neglected the basic consumer desires and needs of its people. The Soviet economy's inability to provide its people was the additional proof for the American people that the Soviet gave up positions to the United States.

Thus, the image of the "Soviet bear", created on the basis of actions of the USSR leaders, organizations in the Union and individual citizens, created in the United States society a certain feeling of threat from the outside. At the same time, the image of this animal provided the idea that the Soviet people, although they thought and acted slowly for the world of that time, still remained an enemy, because as a predatory and powerful bear, they posed a threat to the United States.

No less famous than the rest of the labels associated by the average American citizen with a hostile Soviet regime was the comparison with the "nuclear threat". This term, along with the definitions or phrases "nuclear big stick", "nuclear apocalypse", "red nuclear button", etc. gradually began to occupy part of the minds of Americans from 1947. One of the first mention of this is found on the pages of the American scientific journal "The Bulletin of the Atomic Scientists" which published on its cover image "Doomsday Clock"17. Its clock hands stopped seven minutes before midnight. That is how long, according to leading American scientists, separated the world from the "nuclear apocalypse". In our opinion, the emergence of such a "timer", in the first place, attracted the attention of the educated part of the US population.

This symbol became more popular two years later when its clock hands moved four minutes forward. In that year the USSR conducted the first official test of the atomic bomb, and most Americans started thinking about the real approach of nuclear war with the main enemy - the Soviet Union ${ }^{18}$. As executive director of the aforementioned bulletin $\mathrm{K}$. Benedict said in one of her articles: "Scientists who came up with the idea of moving the clock hands predicted an arms race back in 1945. But then, very few people took it seriously enough. They decided to change the time on the clock to say, "We warned you!" To get more people aware of the importance of the threat"19. Since then, the position of the apocalyptic clock hands had varied according to the level of tension between nuclear superpowers throughout the Cold War ${ }^{20}$.

The threat of nuclear war provoked a feeling of concern among American society. This phenomenon was called "nuclear fear" by American researchers of public opinion. The director of the Center for the History of Physics, $S$. Weart, who had been studying this phenomenon for fifteen years, described it in his book "Nuclear Fear: A History of Images". In particular, he noted that from the very beginning psychologists set themselves the goal of "mobilizing a healthy fear that prompts action and implementation of effective measures against the real danger of war". And so, turned the illusive fears into real ones. The author described how in the United States a certain system of inflating the negative atmosphere arose and resonated,

\footnotetext{
17 The Bulletin of the Atomic Scientists (1947), Retrieved from: https://thebulletin.org/doomsday-clock/ (Accessed 23 May 2019). 18 The Bulletin of the Atomic Scientists (1949), Retrieved from: https://thebulletin.org/sites/default/files/1949\%20Clock\%20Statement\%201.pdf (Accessed 23 May 2019).

19 The Bulletin of the Atomic Scientists (2018), Retrieved from: https://thebulletin.org/2018/01/doomsday-clockwork/ (Accessed 23 May 2019).

20 The Bulletin of the Atomic Scientists, Retrieved from: https:// thebulletin.org/doomsday-clock/past-statements/ (Accessed 23 May 2019).
}

and as a result of any action and message (such as the creation of a civil defense system), instead of reducing the level of panic, contributed to its growth (Weart, 1988: 242).

As a result, in the early $50 \mathrm{~s}$, experts believed that the main danger for the US was no longer the Soviet atomic and hydrogen bombs as a means of armed struggle, but the panic that would arise in the event of war.

The preparation for such a confrontation was not only theoretical but also actively implemented in practice by the American leadership. Thus, in 1950, a federal Civil Defense Agency was established in the United States, under whose leadership people in the country began training "to prepare for an atomic attack"21. The assumptions of possible developments, the visualization of the effects of a nuclear strike on American cities and so on began to be commented on the TV. For example, in 1952, American Television produced the documentary "See It Now", demonstrating to the public what would happen to New York in the event of a nuclear bombing by the USSR ${ }^{22}$. All this could not leave anyone indifferent. "Nuclear Fear" pierced all segments of America's population, from children to adults, from the poor to the rich.

In 1952, just in the middle of "nuclear hysteria", one of the largest publishers of the golden age of comics, "Ace Magazines", released five issues called "Atomic War!". In one of the stories, "damned Russians" threatened the Pentagon, but instead the US Department of Defense was forced to respond preemptively to the Soviet Union's nuclear strike and drop a bomb on Sverdlovsk and turn Chelyabinsk into a ghost town ${ }^{23}$. And another edition of "Fawcett Comics" released the story of one of the most popular superheroes of the time, Captain Marvel, who rescued the United States from the Soviet atomic bomb ${ }^{24}$.

In science fiction novels and feature films, pictures of the death of humankind were revealed. A striking example can be "Dr. Strangelove or: How I Learned to Stop Worrying and Love the Bomb" film, published by American director S. Kubrick in $1963^{25}$. This tape shows all the fears of its generation about nuclear energy, the hype surrounding the construction of bunkers, etc.

The "Bunker Boom" deserves special attention. Using the moment, American business began to make money on the panic mood of people. Many firms offered services for construction of small underground storages. And in 1961, during the Caribbean crisis, businessman M. Preiser founded a firm that traded shelters of a standard "turnkey" construction. The price started from several hundred dollars for which you could get a "construction kit" with metal plates and parts for self-assembly ${ }^{26}$. In addition, for less affluent Americans, air filters, medicines, and even chemical odor absorbers were offered in case one of the

21 Executive Order 10186, Retrieved from: https://www.archives.gov/federal-register/executive-orders/1950.html (Accessed 2 June 2019).

22 "See It Now" (1952), Retrieved from: https://archive.org/details/ seeltNow-29june1952 (Accessed 2 June 2019).

23 "Ace Magazines" (1952), Retrieved from: https://comicbookplus.com/?cid=860 (Accessed 2 June 2019).

24 "Fawcett Comics" (1947), Retrieved from: https://web.archive.org/web/20110128135918/http://marvelfamily.com/whoswho/ whoswho.aspx?castID=344 (Accessed 2 June 2019).

${ }^{25}$ Dr. Strangelove or: How I Learned to Stop Worrying and Love the Bomb, Retrieved from: https://kinogo2.by/8877-doktorstrejndzhlav-ili-kak-ja-nauchilsja-ne-volnovatsja-i-poljubilatomnuju-bombu-1963-smotret-online-na-kinogo.html (Accessed 2 September 2019)

${ }^{26}$ The Survive-All Shelters Sales Kit (1961), Retrieved from: http:/ /conelrad.blogspot.com/2010/09/mad-men-meet-mad-survive-allshelter.html (Accessed 2 September 2019) 
shelter's residents dies. Wealthy people built structures of individual planning, which included, for example, multitone doors that worked from the electric motor. In our opinion, such popularity for certain products only confirms the magnitude of the phenomenon of "nuclear threat" among US citizens.

Politicians also took this opportunity. One of the strongest political videos, with agitational direction, is the "Daisy" film released by the Democratic Party during the 1964 election campaign. The goal was to discredit a rival, rightwing conservative Republican B. Goldwater, who was a supporter of the confrontation with USSR and the nuclear arms race. According to the plot, a little girl tears down the petals of a chamomile and counts: one, two, three ... And then the behind-the-scenes male voice starts counting down: ten, nine, eight. By zero, the child's face is close-up, her eyes are full of horror, and a nuclear explosion grows in them. The film was shown only once two months before the election, but made the impression that many people phoned to the White House, demanding to "stop Goldwater"27.

After the policy of "discharge", under the presidency of R. Reagan, the fight against the "nuclear threat" took a second breath. In a speech on March 23, 1983, he stated: "I have ordered to make a comprehensive and intensive effort to undertake a long-term research and development program to achieve our ultimate goal - to eliminate the threat posed by Soviet strategic nuclear missiles with nuclear warheads" (Reagan, 1989: 289). The US President emphasized that "the Soviet Union has a significant military advantage and the stakes are too high to retreat" (Reagan, 1989: 289). With this speech, the government Strategic Defense Initiative (SDI) program was established. The SDI project attracted considerable public attention as it provided for the deployment of combat lasers; missile systems capable of destroying enemy ballistic missiles in outer space; super-sensors and most powerful computers capable of aiming lasers and interceptor missiles ${ }^{28}$.

This program cast doubts upon the doctrine of "guaranteed mutual destruction", according to which neither the USA nor the USSR were interested in starting a nuclear war, as the aggressor was destroyed guaranteedly.

\section{Conclusion}

Thus, analyzing the American propaganda points in formation of the image of enemy in face of the USSR, it can be noted that the elements of "identification" of all Soviet (with negative connotations) began to be popularized in the United States immediately after the end of the Second World War. In the official speeches of the leaders, periodicals, educational books and fiction, films and television programmes, the Soviet Union was firmly printed as the chimeric, dull and brutal. In the minds of ordinary Americans, the "Iron Curtain" was an insuperable wall on the road to democracy, the "red menace" seemed the world scale evil, and the depicted image of a "Russian bear" caused panic and the need to defend both privately and publicly. However, in our opinion, subconscious dislike for the USSR from the average US citizen in the researched period was more flexible than permanent. At different times, it responded to the needs of informational "conductors" regarding government demands for forming public opinion. This gives reason to claim that the propaganda

27 Daisy (1964), Retrieved from: https://www.youtube.com/ watch?v=dDTBnsqxZ3k (Accessed 2 September 2019)

28 Star Wars, Inc (1987), Retrieved from: https://www.inc.com/ magazine/19870401/3487.html (Accessed 20 October 2019) campaign launched in the US against the USSR was effective and created opportunities for military and political activity of the state. At the same time, we conclude that the US government's information and psychological campaign in the researched area was more of an element of USA policy than a weapon of attack.

\section{REFERENCES}

Barsamian, D. (1992). Stenographers to Power: Media and Propaganda. Monroe, ME: Common Courage Press.

Barson, M. and Heller, S. (2001). Red Scared! The Commie Menace in Propaganda and Popular Culture. San Francisco: Chronicle Books.

Chang, W. H. (1991). Images of the Soviet Union in American newspapers: A content analysis of three newspapers. In: Everette, E. Dennis, George, Gerbner and Yassen, N. Zassoursky, (eds.), Bevond the Cold War: Soviet and American Media Images. Newbury Park, CA: Sage, pp. 65-83.

Drake, F. (February 1958). A Realistic Plan for National Survival. Reader's Digest, pp. 43-47.

Dulles, A. (December, 1954). Progress of Freedom Abroad. Vital Speeches 21: pp. 869-870.

Entman, R. M. (1989). Democracy Without Citizens: Media and the Decay of American Politics. New York: Oxford University Press.

Fish, H. (July 1931). The Menace of Communism. Philadelphia: American Academy of Political and Social Science, pp. 54-61.

Gallup, G. (June 1952), Why We are Doing So Badly in the Ideological War. Vital Speeches 18, pp. 501 -504.

Gamson, W. A. (1992). Talking Politics. Cambridge, UK: Cambridge University Press.

Garthoff, R. L. (1985). Detente and Confrontation: AmericanSoviet Relations from Nixon to Reagan. Washington, DC: The Brookings Institution.

Holstein, L. (2002). Framing the Enemy: Changing u.s. Media Images of China and the U.S.S.R. At the End of the Cold War. ProQuest Information and Learning, Ann Arbor, USA.

Hoover, J. E. (9 June 1947). How to Fight Communism: Ten Don'ts by Mr. Hoover." Newsweek, pp. 30-32.

Jo, M. and Buhle, P. and Georgakas, D. (1997). Encyclopedia of the American Left. New York: Garland Publishing Inc., p. 334-336.

Marx, K. and Engels, F. (1848). Manifesto of the Communist Party by February, p. 446. Retrieved from: https://www.marxists.org/archive/marx/works/download/pdf/Manifesto.pdf (Accessed 15 March 2019).

Morris, Richard B. (1982). Encyclopedia of American History. 6th ed. New York: Harper \& Row Publishers, pp. 424, 453.

Orwell, G. (1949). 1984. p. 231, Retrieved from: http://www.george-orwell.org/1984/1.html (Accessed 25 May 2019).

Parry-Giles, S. J. (1994). Propaganda, effect, and the Cold War: Gauging the status of America's "war of words." Political Communication. 11: 4, pp. 203-213.

Reagan, R. (1989). Speaking My Mind: Selected Speeches. p. 289.

Relations, 1953-1984. Urbana: University of Illinois Press.

Sproule, J. M. (1987). Propaganda studies in American social science: The rise and fall of the critical paradigm. Quarterly Journal of Speech. 73, pp. 60-78.

Stevenson, R. W. (1985). The Rise and Fall of Detente: Relaxation of Tension in U.S.-Soviet. The Macmillan Press Ltd.

Taft, R. (June 1952). Failure of Administration's Foreign Policy. Vital Speeches. 18, pp. 517-520.

Weart, S. R. (1988). Nuclear Fear: A History of Images. Harvard University Press, $535 \mathrm{p}$.

Weisberg, J. (November 28, 1999). Cold War Without End. Retrieved from: https://www.nytimes.com/1999/11/28/magazine/cold-war-without-end.html (Accessed 21 May 2019).

Weldes, J. (1999). Constructing National Interests: The United States and the Cuban Missile Crisis. Minneapolis: University of Minnesota Press. 
Whitney, J. (1954). Women-Russia's Second-Class Citizens. Retrieved from: http://www.writing.upenn.edu/ afilreis/50s/ home.html (Accessed 23 May 2019).

Willis, D. K. (1985). Klass How the Russians Really Lived. New York: St. Martens Press.

\section{LIST OF REFERENCES LINKS}

Barsamian D. Stenographers to Power: Media and Propaganda. Monroe, ME: Common Courage Press, 1992.

Barson M. and Heller S. Red Scared! The Commie Menace in Propaganda and Popular Culture. San Francisco: Chronicle Books, 2001

Chang W. H. Images of the Soviet Union in American newspapers: A content analysis of three newspapers. Bevond the Cold War: Soviet and American Media Images / Everette E. Dennis, George Gerbner and Yassen N. Zassoursky (eds.). Newbury Park, CA: Sage, 1991. pp. 65-83.

Drake F. A Realistic Plan for National Survival. Reader's Digest, February, 1958. Pp. 43-47.

Dulles A. Progress of Freedom Abroad. Vital Speeches 21. December, 1954. Pp. 869-870.

Entman R. M. Democracy Without Citizens: Media and the Decay of American Politics. New York: Oxford University Press, 1989.

Fish H. The Menace of Communism. Philadelphia: American Academy of Political and Social Science, July, 1931, pp. 54-61.

Gallup G. Why We are Doing So Badly in the Ideological War. Vital Speeches 18, June, 1952, pp. 501-504.

Gamson W.A. Talking Politics. Cambridge, UK: Cambridge University Press, 1992.

Garthoff R. L. Detente and Confrontation: American-Soviet Relations from Nixon to Reagan. Washington, DC: The Brookings Institution, 1985.

Holstein L. Framing the Enemy: Changing u.s. Media Images of China and the U.S.S.R. At the End of the Cold War. ProQuest Information and Learning, Ann Arbor, USA, 2002.

Hoover J. E. How to Fight Communism: Ten Don'ts by Mr. Hoover. Newsweek, 9 June 1947. Pp. 30-32.
Jo M., Buhle P., Georgakas D. Encyclopedia of the American Left. New York: Garland Publishing Inc., 1997, p. 334-336.

Marx K., Engels F. Manifesto of the Communist Party by February, 1848. p. 446. URL: https://www.marxists.org/archive/marx/ works/download/pdf/Manifesto.pdf (Accessed 15 March 2019).

Morris Richard B. Encyclopedia of American History. 6th ed. New York: Harper \& Row Publishers, 1982. Pp. 424, 453.

Orwell G. '1984', London (UK): Secker and Warburg, 1949. p. 231. URL: http://www.george-orwell.org/1984/1.html (Accessed 25 May 2019).

Parry-Giles S. J. Propaganda, effect, and the Cold War: Gauging the status of America's "war of words. Political Communication. 1994. No 11:4, pp. 203-213.

Reagan R. Speaking My Mind: Selected Speeches. 1989, p. 289.

Relations, 1953-1984. Urbana: University of Illinois Press.

Sproule J. M. Propaganda studies in American social science: The rise and fall of the critical paradigm. Quarterly Journal of Speech. 1987. No 73, pp. 60-78.

Stevenson R.W. The Rise and Fall of Detente: Relaxation of Tension in U.S.-Soviet, 1985.

Taft R. Failure of Administration's Foreign Policy. Vital Speeches, June, 1952. No 18, pp. 517-520.

Weart S. R. Nuclear Fear: A History of Images. Harvard University Press, 1988. $535 \mathrm{p}$.

Weisberg J. Cold War Without End, November 28, 1999. URL: https://www.nytimes.com/1999/11/28/magazine/cold-warwithout-end.html (Accessed 21 May 2019).

Weldes J. Constructing National Interests: The United States and the Cuban Missile Crisis. Minneapolis: University of Minnesota Press, 1999.

Whitney J. Women-Russia's Second-Class Citizens. 195. URL: http://www.writing.upenn.edu/ afilreis/50s/home.html (Accessed 23 May 2019).

Willis D. K. Klass How the Russians Really Lived. New York: St. Martens Press, 1985.

Вадим Беспека,

Національна академія Сухопутних військ імені гетьмана Петра Сагайдачного (м. Львів, Україна)

e-mail:vadim12323@ukr.net, ORCID 0000-0001-6934-1610

\section{ПРОПАГАНДА США В ПЕРІОД ХОЛОДНОЇ ВІЙНИ: ФОРМУВАННЯ ОБРАЗУ ВОРОГА В ОСОБІ СРСР}

Аналіз асиметричних загроз у минулих збройних протистояннях дозволяє здійснити оцінку ризиків у подібних ситуаціях сьогодні. Холодна війна 1946-1991 років не є виключенням, оскільки саме досвід застосування пропагандистського впливу обома сторонами у ній є невичерпним джерелом для узагальнення і прогнозування тих процесів довкола російсько-українського конфлікту, які поступово окреслюються сучасними воєнними та політичними експертами як "холодна війна XXI столітя". Існуючі на пострадянському просторі публікації за окресленою у статті проблематикою здебільшого сильно страждають на ортодоксальність своїх поглядів. Це обмежує можливість об'єктивно оцінити форми і способи формування громадської думки в США щодо політичного ворога після Другої світової війни, а отже збіднює знання щодо можливих варіантів розгортання подій для нашої держави у протистояння такого типу, а, відповідно, можливість прогнозування ситуації. У запропонованому дослідженні зроблено спробу відмежуватись від радянських та пострадянських джерел інформації і на основі виключно американських публікацій виокремити основні кліше, сформовані в інформаційному просторі США щодо образу ворога в особі СРСР.

Ключові слова: Холодна війна; образ ворога; пропаганда; червона загроза; ядерна загроза; залізна завіса.

(C) Vadym Bespeka

Надійшла до редакції: 30.10 .2019

Прийнята до друку: 18.11.2019 